\title{
Potential clinical implications of the urotensin II receptor antagonists
}

\section{Philip Tsoukas, Émilie Kane and Adel Giaid*}

Division of Cardiology, Department of Medicine, Montreal General Hospital, McGill University Health Center, Montreal, OC, Canada

\section{Edited by:}

Issy Laher, University of British

Columbia, Canada

Reviewed by:

Yu Huang, Chinese University of Hong-Kong, China

Chris R. Triggle, Weill Cornell Medical College in Qatar, Qatar

*Correspondence:

Adel Giaid, Montreal General Hospital, Suite L3-109, 1650 Cedar Avenue,

Montreal, OC, Canada H3G 1A4.

e-mail: adel.giaid@mcgill.ca
Urotensin II (UII) binds to its receptor, UT, playing an important role in the heart, kidneys, pancreas, adrenal gland, and central nervous system. In the vasculature, it acts as a potent endothelium-independent vasoconstrictor and endothelium-dependent vasodilator. In disease states, however, this constriction-dilation equilibrium is disrupted. There is an upregulation of the UII system in heart disease, metabolic syndrome, and kidney failure. The increase in UII release and UT expression suggest that UII system may be implicated in the pathology and pathogenesis of these diseases by causing an increase in acyl-coenzyme A:cholesterol acyltransferase-1 (ACAT-1) activity leading to smooth muscle cell proliferation and foam cell infiltration, insulin resistance (DMII), as well as inflammation, high blood pressure, and plaque formation. Recently, UT antagonists such as SB-611812, palosuran, and most recently a piperazino-isoindolinone based antagonist have been developed in the hope of better understanding the UII system and treating its associated diseases.

Keywords: UT, heart, metabolic syndrome, kidney, antagonist

\section{INTRODUCTION}

Urotensin II (UII) was first isolated in the 1960s from a goby fish indigenous to the Californian coastline. Since, it has been identified as an 11 amino acid peptide derived from larger 124 (alpha) and 139 (gamma) amino acid prepro-UII encoded by a single gene (Ames et al., 1999). It is expressed in species ranging in the evolutionary levels, all isoforms having a conserved cyclic hexapeptide core-sequence motif of CFWKYC (Colton et al., 1996). UII binds to the Gq protein urotensin II receptor, UT, known originally as the orphan GPR14 receptor (Ames et al., 1999). This receptor has been identified in varying quantities (Maguire et al., 2000) in cardiac myocytes, vascular smooth muscled cells (SMC), endothelial cells, spinal cord, central nervous system (CNS), and kidneys (Ames et al., 1999; Liu et al., 1999; Matsushita et al., 2001; Maguire et al., 2004; Zhu et al., 2006). UII, on the other hand, has been detected by immunohistochemistry in blood vessels from the heart, pancreas, kidney, placenta, thyroid, adrenal gland, and umbilical cord, as well as in human epithelial cells of the kidneys (Shenouda et al., 2002; Silvestre et al., 2004; Zhu et al., 2006). Both ligand and receptor seem to be ubiquitously expressed in human tissues (Douglas et al., 2004a), though lymphocytes and macrophages, respectively, are the largest producers of UII and UT in sites of atherosclerotic lesions (Bousette et al., 2004).

Urotensin II has been defined as the most potent vasoconstrictor to date as it is approximately 10 -fold more potent than ET-1 (Ames et al., 1999). Yet, stimulation of UT can also trigger the release of nitric oxide (NO), prostacyclin, prostaglandin $\mathrm{E}_{2}$, and endothelium-derived hyperpolarizing factors to balance the contractile effect on SMCs (Gibson, 1987; Bottrill et al., 2000; Douglas and Ohlstein, 2000; Katano et al., 2000; MacLean et al., 2000; Gray et al., 2001; Camarda et al., 2002; Zhang et al., 2003; Ishihata et al., 2005; Gardiner et al., 2006; Lacza and Busija, 2006). Vasoconstriction is mediated by receptors on
SMCs, whereas vasodilation is endothelium-mediated (Douglas et al., 2004a). However, in a disease state of chronic heart failure or essential hypertension, UII loses its dilatory ability (Lim et al., 2004; Sondermeijer et al., 2005). It is understood that such a loss and dysfunction of endothelial cells would favor a contractile response over a relaxant one (Lim et al., 2004). Hence, UII causes endothelium-independent vasoconstriction and endothelium-dependent vasodilation. In fact, the contractile response of rat aorta UII decreased from 79 to $33 \%$ in the presence of the endothelium (Bottrill et al., 2000; Ishihata et al., 2006). The complex and contrasting vascular action of UII is not only dependent on the condition of the endothelium, but also on the vascular bed type and species (Douglas et al., 2000, 2002).

In a healthy human, UII functions as a chronic regulator of vascular tone rather than influencing regions in a phasic manner (Douglas and Ohlstein, 2000). Its "pseudo-irreversible" binding properties and slow dissociation rate from the UT receptor leads to prolonged activation of UT and to a functionally silent system (Douglas et al., 2004a,b). In patients with cardiovascular disease, this state of equilibrium is disturbed as they experience an upregulation of UT (Douglas et al., 2002) and of UII in atherosclerotic lesions (Ames et al., 1999; Maguire et al., 2004; Hassan et al., 2005) resulting in vasoconstriction. Elevated plasma UII levels are found in patients with heart failure (Douglas et al., 2002; Ng et al., 2002; Richards et al., 2002; Russell et al., 2003; Lapp et al., 2004), congestive heart failure (Douglas et al., 2002; Richards et al., 2002), carotid atherosclerosis, renal failure (Totsune et al., 2003), renal dysfunction (Totsune et al., 2001), portal hypertension-cirrhosis (Heller et al., 2002), diabetes mellitus (Totsune et al., 2004), and essential hypertension (Matsushita et al., 2001; Cheung et al., 2004; Suguro et al., 2007). Although UII levels are always higher in patients than controls, higher levels can also correlate with a decreased chance of adverse outcome, suggesting a protective role (Khan et al., 2007). In 
fact, some suggest that UII can counteract sympathetic and natriuretic cardiovascular risk factors (Mallamaci et al., 2005), and have a restorative effect on endothelial function (Zoccali et al., 2006).

\section{PATHOLOGY AND PATHOPHYSIOLOGY}

Urotensin II acts as a mitogenic and hypertrophic agent resulting, in part, in the enlargement of cells and in the reorganization of sarcomeres. These cellular responses result from UT receptor-binding which promote tyrosine phosphorylation of epidermal growth factor (EGF) receptor and in turn activate mitogen-activating protein kinases (MAPK), extracellular signal-regulated kinase 1/2 (ERK 1/2), and p38 (Sauzeau et al., 2001; Zou et al., 2001; Tamura et al., 2003; Onan et al., 2004). UII also increases cell proliferation in vascular SMCs (Sauzeau et al., 2001; Watanabe et al., 2001a,b; Tamura et al., 2003) by acting synergistically with oxidized low-density lipoproteins (LDL), amongst several other mitogens (Watanabe et al., 2001a,b, 2002). In addition, the remodeling process is affected by the UII-induced release of inflammatory cytokines such as interleukin-6 (IL-6) from cardiomyocytes (Sano et al., 2000; Tzanidis et al., 2003; Johns et al., 2004; Russell and Molenaar, 2004). Procollagen, an integral part of myocardial remodeling, is also upregulated in fibroblasts by UII activation of TGF- $\beta 1$ (Tzanidis et al., 2003; Dai et al., 2007). Such pro-fibrotic effects lead to cellular hypertrophy, protein synthesis, and the expression of natriuretic factors, all induced by UII (Tzanidis et al., 2001, 2003; Zou et al., 2001). UII has also been shown to increase expression of NADPH oxidase and plasminogen activator inhibitor-1 (PAI-1) in vascular SMCs (Djordjevic et al., 2005), likely leading to hypoxiainduced hypertension and atherosclerosis (Pakala, 2007). Hence, UII might be involved in the etiology of heart failure (Douglas et al., 2002; Ng et al., 2002; Richards et al., 2002) and might contribute to the development of essential (Matsushita et al., 2001) and secondary (Heller et al., 2002) hypertension via remodeling of the vasculature.

\section{CARDIOVASCULAR DISEASE}

Endothelial cell dysfunction causes vasoconstriction or inadequate vasodilation resulting in myocardial ischemia and hypertension (Zhang et al., 2002; Wang et al., 2003; Zhou et al., 2003; Russell and Molenaar, 2004), associated with an increase in UII and UT. In fact, there is a 3.4-fold increase of the UII system in patients with hypertension (Suguro et al., 2007). There is also a positive correlation between the extent of congenital heart failure (CHF) and plasma UII levels (Ng et al., 2002; Richards et al., 2002; Douglas, 2003; Russell et al., 2003; Lapp et al., 2004; Gruson et al., 2006). hUII plasma concentration in 88 patients with heart failure was shown to be 2.1-fold higher compared to 74 age-matched controls (Richards et al., 2002). In children with CHF, the plasma hUII plasma level was also significantly elevated (Simpson et al., 2006). It has been suggested that the upregulation of myocardial hUII may contribute to impaired myocardial function under disease conditions such as CHF (Hassan et al., 2003), as in high concentrations, hUII leads to a collapse of the cardiovascular system and death in primates due to a dramatic reduction of heart rate, mean blood pressure, first-order derivative of left ventricular pressure, and carotid and coronary blood flow (Ames et al., 1999). UII is also correlated with left ventricular end-diastolic dimensions and negatively correlated with the left ventricular ejection fraction (Douglas et al., 2002; Gruson et al., 2006). Increased expression of UII and UT has also been associated with human coronary atherosclerosis (Maguire et al., 2004; Hassan et al., 2005), left ventricular hypertrophy, and fibrosis (Hunt et al., 2001).

Urotensin II is upregulated in regions of macrophage infiltration at atherosclerotic lesions (Bousette et al., 2004). It may thus accelerate the development of atherosclerosis in hypertensive patients by acting synergistically with mildly oxidized-LDL and inducing proliferation of vascular SMCs (Watanabe et al., $2001 a, b)$. The formation of foam cells is another key feature of atherosclerosis affected by an upregulation in UII which increases acyl-coenzyme A:cholesterol acyltransferase-1 (ACAT-1) expression in macrophages (Watanabe et al., 2005). UII may also play a role in myocardial fibrogenesis as it increases procollagen and fibronectin synthesis in rat fibroblasts (Zou et al., 2001). A significant increase of $23 \pm 2 \%$ of collagen peptide synthesis was observed in rats with heart failure with elevated levels of UII and UT (Tzanidis et al., 2003; Russell and Molenaar, 2004). UII is also upregulated in myointimal cells and induces extracellular matrix deposition contributing further to the vascular remodeling associated with restenosis (Rakowski et al., 2005). In addition, a significant increase in UII-dependent activation of hypertrophic signals was observed in cardiomyocytes (Zou et al., 2001; Tzanidis et al., 2003; Johns et al., 2004; Onan et al., 2004). The use of UT antagonists on animal models of cardiovascular disease has led to improvements in hemodynamics and cardiovascular remodeling, suggesting that UII is involved in the development of disease. The heart is one of the tissues with the highest UT expression (Ames et al., 1999), further supporting its role in cardiovascular physiology (Figures 1 and 2).

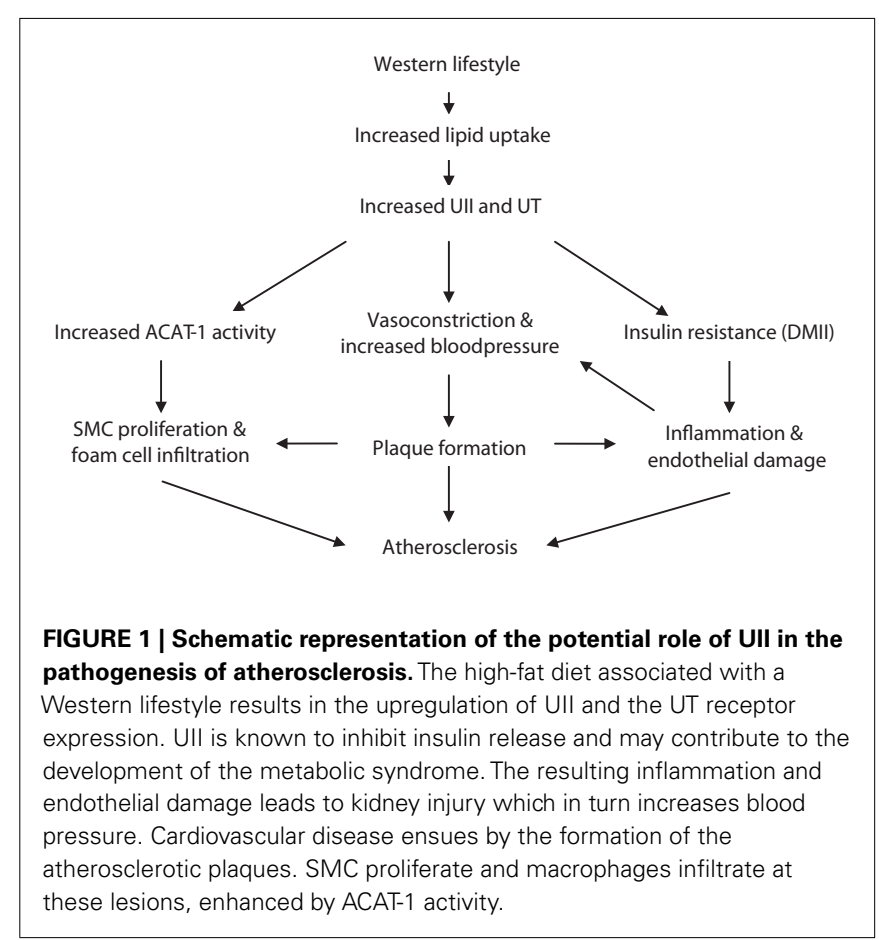




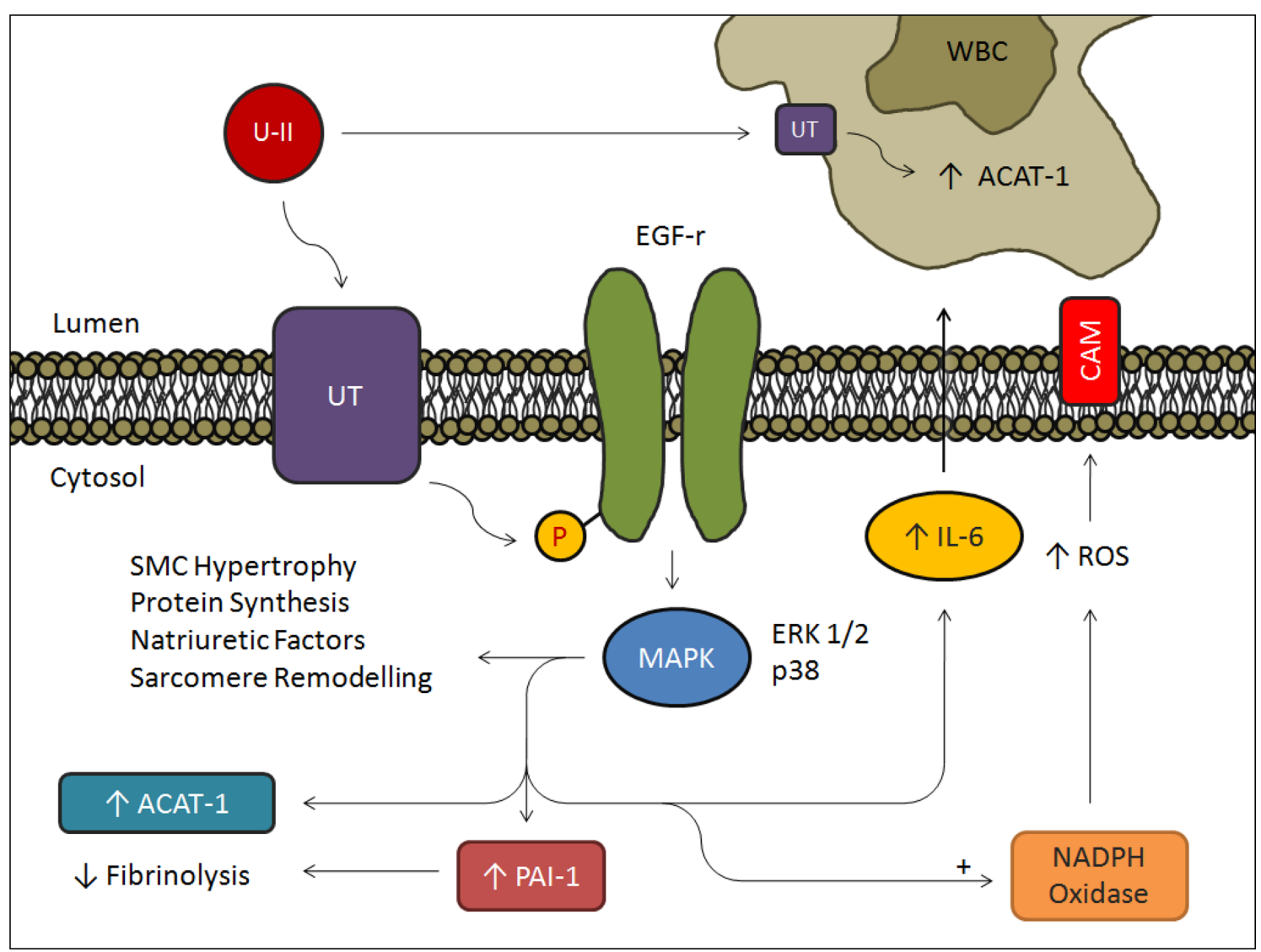

FIGURE 2 | Summary schematic of the effects of UII in endothelial cells, vascular SMCs, and macrophages. Stimulation of UT with UII induces phosphorylation of EGF receptor and activation of ERK1/2 and p38 pathways leading to mitogenic changes in SMCs and an increase in IL-6, PAI-1, and
ACAT-1. Furthermore, stimulation of NADPH Oxidase increases cell adhesion molecule expression promoting macrophage infiltration in atherosclerotic vessels. UII binding to macrophage UT increases macrophage ACAT-1 resulting in increased lipid uptake and subsequent foam cell production.

\section{METABOLIC SYNDROME}

In addition to affecting vascular tone and cardiac health, UII also has a role in insulin secretion and the pathogenesis of type II diabetes mellitus (DMII; Figure 3). Both UII and UT are present in the human pancreas and seem to directly inhibit beta cell function, thus inhibiting insulin release (Ames et al., 1999; Silvestre et al., 2001; Elshourbagy et al., 2002). In fact, UII levels have been reported to be 1.7-fold higher in diabetic patients than in healthy controls. However, UII levels did not correlate with fasting blood sugar levels demonstrating that hyperglycemia is not responsible for UII increase. It has been suggested that elevated UII plasma concentrations in metabolic syndrome may be a result of damaged endothelial cells, as is the case in cardiovascular diseases (Totsune et al., 2003). The metabolic syndrome, which includes DMII, is associated with increased inflammatory cytokines and elevated free fatty acids across its spectrum (Bergman and Ader, 2000; Saltiel and Kahn, 2001; Rajala and Scherer, 2003; Wellen and Hotamisligil, 2003). In fact, UII can upregulate IL-6 which plays a role in atherogenesis and hypertrophy, as well as in insulin resistance (Fernandez-Real and Ricart, 2003; Johns et al., 2004). Insulin resistance may further impair vasodilation, as plasma insulin levels and blood pressure are correlated in patients with hypertension
(Sowers, 2004). Interestingly, several SNPs identified on the hUII gene have been associated with insulin resistance and therefore with a susceptibility to DMII (Totsune et al., 2003; Suzuki et al., 2004). In addition, DMII patients with renal dysfunction exhibited plasma and urine UII levels higher than in patients with normal function (Totsune et al., 2004). These elevated levels are probably due to an increased production of UII in renal tubular cells as a result of renal damage (Matsushita et al., 2001; Totsune et al., 2003). In effect, insulin resistance causes increased blood pressure and consequently results in atherosclerosis and renal damage (El-Atat et al., 2004).

\section{RENAL DISEASE}

In 2003, a joint publication by a panel of nephrologists and cardiologists demonstrated the importance of kidney disease as a risk factor for the development of cardiovascular disease (Tölle and van der Giet, 2008). The kidney plays an important role in controlling cardiovascular homeostasis, influencing both cardiac preload and afterload, and regulating vasomotor tone (Douglas et al., 2004a). The kidneys are a major source of UII and UT and due to either a reduced renal clearance or increased renal UII production (Figure 4). Urinary concentrations of UII are significantly 


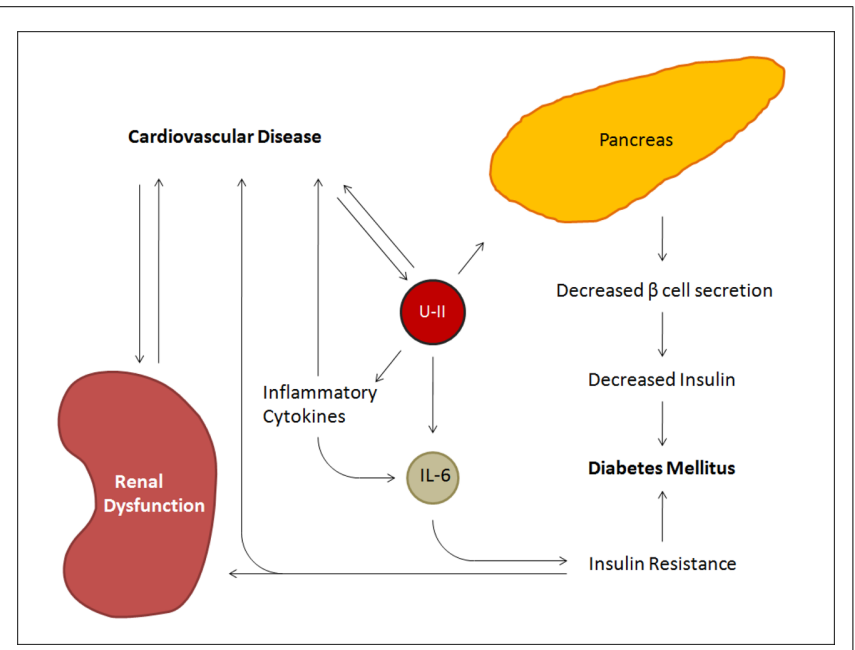

FIGURE 3 | Summary schematic of the effects of UII on the metabolic syndrome. In addition to the cardiorenal aspects influenced by urotensin, UII increases circulating levels of inflammatory cytokines, including IL-6, resulting in insulin resistance. It further acts directly on the pancreas to decrease beta cell secretion.

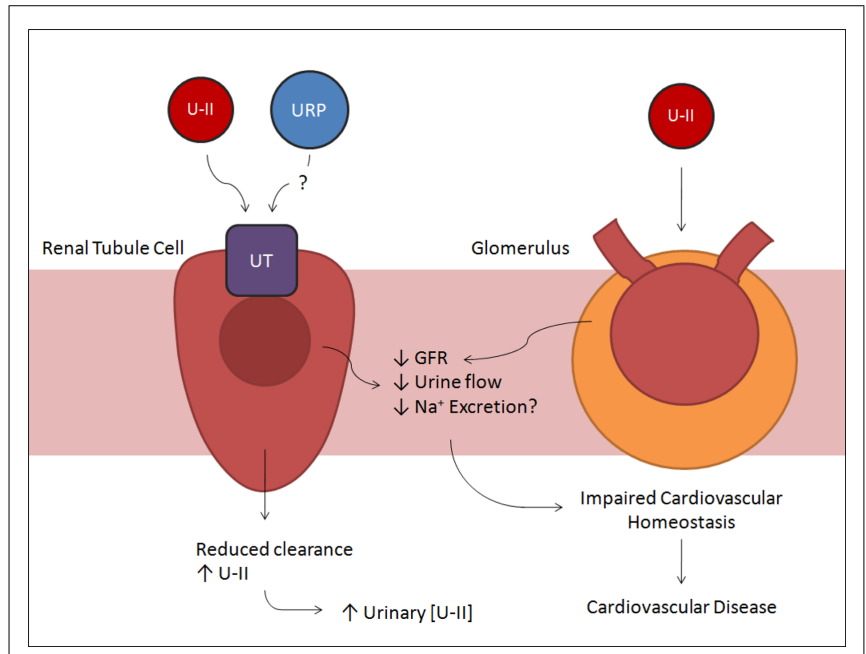

FIGURE 4 | Summary schematic of the effects of UII in the renal tubules and glomerulus. Urotensin and possibly urotensin-related protein binding to UT in renal tubule cells results in decreased urine flow. In addition, UII acting at the glomerulus directly decreases glomerular filtration rate. These effects impair normal cardiovascular homeostasis, increasing blood pressure, and promoting cardiovascular disease.

increased with renal tubular disease (Matsushita et al., 2001). In comparison to controls, patients with chronic renal failure had a two-fold increase in hUII-like immunoreactivity concentrations (Bohm and Pernow, 2002), and in patients with diabetic nephropathy, biopsies revealed a 45 -fold increase in UII and a 2000 -fold increase in UII receptors (Langham et al., 2004). Bolus injections of rat UII in the low pmol/100 g body weight range have actually demonstrated dose-related reductions in glomerular filtration rate (GFR), urine flow, and sodium excretion rate (Song et al.,
2006). However, other studies saw only a modest reduction in GFR and no change in sodium excretion (Ovcharenko et al., 2006). Such discrepancies may be explained by a lack of consistency in experimental design and of consensus on methods.

For example, renal UT receptors, the majority of which are found in the renal medulla (Disa et al., 2005), have been shown to also bind the urotensin-related peptide (URP; Ashton, 2006). If the URPs that bind to UT actually stimulate the receptor, then many UII-like immunoreactivity studies may have considerably underestimated the significance of the UII system in regulating a variety of pathophysiological conditions (Russell, 2008). All methods have the risk of including or excluding precursor molecules and metabolites of UII that may or may not be active. Antibody-based methods are not specific for hUII and detect hUII metabolites as well. In fact, there is currently no consensus on a reliable method to measure plasma hUII (Tölle and van der Giet, 2008). Regardless of the method, when measuring plasma UII concentrations, it is important to exclude individuals with co-existing diseases associated with elevated UII concentrations. When working with animal models, it is important to consider that UII from different species induce different effects in identical physiological models (Li et al., 2004). The contrary is also true when considering the varying effects of hUII in rats, C57/B18 mice, pigs, cynomolgus monkeys, and marmosets (Douglas et al., 2000). The UII source and animal model must also be considered working with isolated vessels, as well as the choice of vessel segment (Camarda et al., 2002). The lack of consensus in methods and models has lead to many conflicting reports on the effects of UII in numerous disease states including cardiovascular disease, metabolic syndrome, and renal disease. The lack of a proper pathway is in part due to this situation.

Urotensin II is upregulated in a number of disease states. When acute symptoms arise, UII is temporarily upregulated in order to repair the damage caused and it later returns to its normal levels. This would explain how the upregulation of UII is an inverse predictor of adverse clinical outcome in patients with acute coronary syndromes (Khan et al., 2007). A chronic increase of the UII system, on the other hand, can lead to the development of several diseases, namely cardiovascular disease (Figures 1 and 2), metabolic syndrome (Figure 3), and renal disease (Figure 4). These three disease states are not only interconnected as described above, they also share an instigator in a Western lifestyle consisting of too little exercise and excessive lipid consumption. Such habits lead to central obesity, increased blood pressure, raised triglycerides, and reduced HDL cholesterol, all symptoms of the metabolic syndrome. They are further associated with an increase in UII leading to insulin resistance, inflammation, and endothelial damage, which are themselves independent risk factors for cardiovascular and renal diseases (Grundy et al., 2005; IDF Epidemiology Task Force Consensus Group, 2005). Endothelial damage in the kidneys upregulates the local UII system causing endothelial-independent vasoconstriction. This is an additional source of pressure load to that already caused by a poor lifestyle. Increased blood pressure and resulting plaque formation leads to diseased arteries (Heller et al., 2002; Cheung et al., 2004; Lapp et al., 2004; Balat et al., 2005; Suguro et al., 2007). Ensuing arterial lesions attract monocytes which interact with oxidized-LDL to form macrophages and foam 
cells. UII increases acetyl-LDL-induced cholesterol ester accumulation in macrophages to ACAT-1, increasing the amount of foam cells. Interestingly, the lymphocytes and macrophages already at the lesion are respectively the largest producers of UII and UT receptors (Bousette et al., 2004). This increase of the UII system at atherosclerotic lesions results in further lesion formation by inducing SMC growth and migration, collagen production, foam cell formation (Watanabe et al., 2005). The cycle perpetuates itself in the heart, kidney, and pancreas as long as excess lipid is present in the system. A recent study suggests that a UT receptor gene knock-out has decreased lipid uptake and storage due to the downregulation of lipoprotein uptake receptors and the attenuation of ACAT activity (Bousette et al., 2009). This suggests that in an attempt to regulate elevated lipid levels, the UII system is upregulated to increase the amount of available lipid receptors. The increased lipid uptake by hepatocytes will influence metabolic syndrome as the liver is the main source of glycogen. On the other hand, the upregulation of ACAT-1 in hepatocytes will increase the release of LDL, and in macrophages it will increase the formation of foam cells along with this same increased LDL.

\section{ANTAGONISTS}

In hopes of a new treatment for cardiovascular disease, metabolic syndrome, and renal disease, the altered UII system in disease states has prompted the development of a number of UT receptor antagonists (Table 1). Several peptide antagonists share a

Table 1 | Clinical findings, dosages, and affinities of current UT antagonists.

\begin{tabular}{|c|c|c|c|c|c|}
\hline & Type & Study & Dosage & Findings & UT affinity \\
\hline \multirow[t]{3}{*}{ Urantide } & $\begin{array}{l}\text { Competitive } \\
\text { antagonist }\end{array}$ & Patacchini et al. (2003) & $0.1 \mathrm{nM}-10 \mu \mathrm{M}$ & Effects on rat aorta & $\begin{array}{l}\mathrm{p} K_{\mathrm{i}}=8.3 \\
\text { (Patacchini et al., 2003) }\end{array}$ \\
\hline & & Watanabe et al. (2005) & $25 \mathrm{nM}$ & $\begin{array}{l}\text { Inhibition of ACAT-1 } \\
\text { upregulation, } \\
\text { macrophages }\end{array}$ & \\
\hline & & Camarda et al. (2004) & $\begin{array}{l}10 \mathrm{nM}, 100 \mathrm{nM} \\
1000 \mathrm{nM}, 10 \mu \mathrm{M}\end{array}$ & $\begin{array}{l}\text { Agonist activity, } \\
\text { overexpression of UT }\end{array}$ & \\
\hline \multirow[t]{2}{*}{ BIM-23127 } & $\begin{array}{l}\text { Competitive } \\
\text { antagonist }\end{array}$ & Herold et al. (2003) & $33 \mathrm{nM}-3.3 \mu \mathrm{M}$ & $\begin{array}{l}\text { Inhibited } \mathrm{Ca}^{2+} \\
\text { mobilization, embryonic } \\
\text { kidney cells }\end{array}$ & $\begin{array}{l}\mathrm{p} K_{\mathrm{i}}=6.7 \\
\text { (Herold et al., 2003) }\end{array}$ \\
\hline & & Johns et al. (2004) & $3 \mu \mathrm{M}$ & $\begin{array}{l}\text { Inhibited cardiomyocyte } \\
\text { hypertrophy }\end{array}$ & \\
\hline \multirow[t]{4}{*}{ SB-611812 } & $\begin{array}{l}\text { Non-peptide } \\
\text { competitive } \\
\text { antagonist* }\end{array}$ & Rakowski et al. (2005) & 30 mg/kg/day & $\begin{array}{l}\text { Reduced induced intimal } \\
\text { hyperplasia }\end{array}$ & $\begin{array}{l}K_{\mathrm{i}}=121 \mathrm{nM} \\
\text { (Rakowski et al., 2005) }\end{array}$ \\
\hline & & Bousette et al. (2006b) & 30 mg/kg/day & Improved CHF & \\
\hline & & Tzanidis et al. (2003) & 30 mg/kg/day & Reduced remodeling (CHF) & \\
\hline & & Bousette et al. (2006b) & 30 mg/kg/day & Reduced fibrosis & \\
\hline \multirow[t]{4}{*}{$\begin{array}{l}\text { Palosuran } \\
\text { (ACT-058362) }\end{array}$} & $\begin{array}{l}\text { Non-peptide } \\
\text { competitive } \\
\text { antagonist }\end{array}$ & Clozel et al. (2004) & $10 \mathrm{mg} / \mathrm{kg} \mathrm{h}$ & $\begin{array}{l}\text { Reduced } \mathrm{Ca}^{2+} \text { influx, } \\
\text { inhibits MAPK } \\
\text { phosphorylation, improved } \\
\text { renal function }\end{array}$ & $\begin{array}{l}K_{i}=5 \mathrm{nM} \\
(\text { Behm et al., 2008)** }\end{array}$ \\
\hline & & Clozel et al. (2006) & 300 mg/kg/day & $\begin{array}{l}\text { Increased survival, } \\
\text { improved metabolic } \\
\text { syndrome }\end{array}$ & \\
\hline & & Sidharta et al. (2006) ${ }^{\dagger}$ & 125 mg bid & $\begin{array}{l}\text { Improvement of diabetic } \\
\text { nephropathy, } \\
\text { microalbuminuria }\end{array}$ & \\
\hline & & Sidharta et al. $(2009)^{\dagger \dagger}$ & 125 mg bid & $\begin{array}{l}\text { No effect on insulin } \\
\text { secretion, sensitivity, } \\
\text { glucose levels in DMII }\end{array}$ & \\
\hline $\begin{array}{l}\text { Piperazino- } \\
\text { isoindolinone based } \\
\text { antagonist }(7 a)^{\ddagger}\end{array}$ & $\begin{array}{l}\text { Non-peptide } \\
\text { U-II antagonist }\end{array}$ & Lawson et al. (2009) & $10 \mathrm{mg} / \mathrm{kg}$ & $\begin{array}{l}\text { Reduction of ear pinna } \\
\text { temperature }\end{array}$ & $\begin{array}{l}K_{\mathrm{i}}=4.0 \mathrm{nM} \\
\text { (Lawson et al., 2009) }\end{array}$ \\
\hline
\end{tabular}

${ }^{*}$ No agonist activity (Bousette et al., 2006b).

** Low binding in non-primates ( $K_{i}>1.0 \mu \mathrm{M}$; Behm et al., 2008).

${ }^{\dagger} n=19$, no control group, continuation of medications (ACE, ARBs; Sidharta et al., 2006).

${ }^{\dagger \dagger} n=20$ (Sidharta et al., 2009).

‡Oral bioavailability needs improvement (Lawson et al., 2009). 
common cyclic region, similar to the conserved region of UII. One of these compounds, urantide, acts as a competitive antagonist, selectively blocking UII-induced effects in the rat aorta (Patacchini et al., 2003). It significantly inhibited UII-induced ACAT-1 upregulation in cultured human monocyte-derived macrophages (Watanabe et al., 2005). However, urantide has been reported to act as an agonist in cells overexpressing recombinant human UT receptors (Camarda et al., 2004). Another peptide UT receptor antagonist, BIM-23127, is competitive for the rat UT receptor (Behm et al., 2002) and a full agonist at the recombinant hUT receptor (Herold et al., 2003). BIM-23127 inhibited calcium mobilization in human embryonic kidney cells expressing UT receptors (Herold et al., 2003), and inhibited UII-induced hypertrophy in cultured H9c2 cardiomyocytes (Johns et al., 2004). While the data generated with BIM-23127 should be interpreted cautiously because of its roughly equal affinity for the neuromedin B receptor (Lach et al., 1995), it nonetheless represents the most potent UT receptor antagonist characterized to date (Herold et al., 2003).

\section{SB-611812}

The non-peptide antagonist SB-611812 is highly selective for the $\mathrm{UT}$ receptor and is devoid of any agonist activity, which has been a hindrance with previous UT antagonists (Bousette et al., 2006a). It attenuates UII-induced intimal hyperplasia in a rat model of balloon angioplasty-mediated restenosis. Rats treated with SB611812 (30 mg/kg/day) following balloon angioplasty had 60\% less intimal thickening than vehicle-treated animals (Rakowski et al., 2005). These results raise the possibility that UII antagonists may play a role in preventing post-angioplasty arterial stenosis. In addition, Bousette et al. (2006a) demonstrated that SB-611812 attenuates cardiac dysfunction in a rat model of CHF induced by coronary ligation. In this study, rats underwent an 8week ligation of the left anterior descending coronary artery or sham surgery, and were treated with SB-611812 (30 mg/kg/day) or vehicle for 8 weeks. Those treated with the UT antagonist had significantly reduced mortality and improved CHF compared to controls. In fact, the treatment decreased hypertrophy by $54 \%$, ventricular dilatation by $79 \%$, pulmonary edema by $71 \%$, left ventricular end-diastolic pressure by $72 \%$, right ventricular systolic pressure by $92 \%$, and central venous pressure by $59 \%$. This demonstrates not only that UII plays an important role in cardiovascular function, but also that blocking UT receptors can decrease mortality and improved cardiac function. With the same rat $\mathrm{CHF}$ model and treatment regimen, Bousette et al. (2006a) also demonstrated that SB-611812 can reduce interstitial fibrosis and remodeling following CHF. UII has been shown in the past to have pro-fibrotic effects as it induces collagen type I and type II, as well as fibronectin in fibroblasts (Tzanidis et al., 2003). As predicted, blocking UT with SB-611812 decreased myocardial and endocardial fibrosis and reduced collagen deposition resulting in attenuated cardiac remodeling. Therefore, the antagonisttreated group had improved cardiac function in comparison to controls (Bousette et al., 2006b). Together, these studies demonstrate an improvement in cardiac function and an attenuation of cardiac remodeling after CHF with the use of SB-611812, further promoting the development of UT receptor antagonists in hopes of ameliorating cardiac health. Although the studies show a potential advantage to UII blockade in humans, caution must be used with the results as only a small number of animals were studied.

\section{PALOSURAN}

ACT-058362, commonly known as palosuran, is another nonpeptide UT receptor antagonist with promise in drug development. In radioligand binding experiments using ${ }^{125} \mathrm{I}-\mathrm{UII}$ in cell and membrane preparations expressing human UT receptor, palosuran interacted competitively and specifically with hUT (Clozel et al., 2004). Palosuran inhibits ${ }^{125}$ I-UII binding to hUT in membrane preparations with nearly equal potency as native hUII, but with dramatically lower potency for the rat UT receptor. In intact cells, palosuran also has significantly reduced antagonistic properties compared to membrane preparations. In Chinese hamster ovary $(\mathrm{CHO})$ cells transfected with hUT, palosuran has 100 -fold lower inhibitory potency than native UII and CHO cells transfected with rat UT, has very low efficacy. Nevertheless, in hUT and rat UT transfected cells, palosuran inhibits UII-induced calcium influx in a dose-dependent manner. It also has the ability to inhibit UII-induced MAPK phosphorylation in CHO cell transfected with hUT, suggesting an anti-inflammatory role (Clozel et al., 2004). In animal models, it did not have any significant effect on renal blood flow or serum sodium concentration, nor did it change the mean arterial pressure, heart rate, or mean renal blood flow (Clozel et al., 2004). However, in a rat model of renal ischemia, palosuran prevented both postischemic renal vasoconstriction and reduced postischemic acute renal failure. It attenuated both the decreased tubular sodium reabsorption and the increased fractional excretion of sodium. It also significantly decreased tubulointerstitial lesions, decreasing the severity of changes (Clozel et al., 2004). Palosuran improved renal dysfunction and injury induced ischemia, revealing not only a role of UII in the pathogenesis of ischemia in acute renal failure, but also an opportunity for treatment in humans. However, its lack of effect on systemic blood flow suggests it is local to the kidneys. In addition, Clozel et al. (2004) stated that the binding affinity of palosuran to the rat UT in intact $\mathrm{CHO}$ cell is very low $\left[\mathrm{IC}_{50}(\mu \mathrm{M})>10\right]$, yet they administered palosuran in a dose of $10 \mathrm{mg} /(\mathrm{kg} \mathrm{h})$ resulting in a plasma concentration of approximately $5 \mu \mathrm{M}$ (Tölle and van der Giet, 2008). Interestingly, this concentration was not able to inhibit rat UT in vitro, but showed efficacy in vivo in rat.

In a follow-up study, Clozel et al. (2006) investigated the effect of a 25 -week oral treatment of palosuran $(300 \mathrm{mg} / \mathrm{kg} /$ day $)$ in diabetic rats. Rats were treated with streptozocin (STZ), as it destroys pancreatic $\beta$-cells and results in insulin-sensitive hyperglycemia and associated complications, to establish a model of type 1 diabetes. Treatment with palosuran more than doubled the number of diabetic rats that survived. Palosuran halved the increase in cholesterol and largely prevented the increase in triglycerides. It also increased glucose tolerance, increased insulin levels and slowed the increase in glycemia, and glycosylated hemoglobin. This results in a delayed development of proteinuria and renal damage (Clozel et al., 2006). The slowed progression of diabetes due to an increase in glucose tolerance and a decrease in 
proteinuria furthers the clinical possibilities of UII system blockade. However, the authors studied a model of type 1 diabetes, whereas UII-induced diabetes is known to be of type 2. Although both models represent an abnormal metabolism, type 1 diabetes is characterized by a lack of insulin due to the autoimmune destruction of $\beta$-cells, and type 2 represents insulin resistance and deficiency. Also, the authors studied yet again the effects of UII antagonism in rat, where the binding affinity of palosuran is very low, and administered a palosuran regimen similar to the previous study, where plasma concentrations should be below efficacy.

In the first palosuran study on humans, Sidharta et al. (2006) treated patients of both sexes afflicted by hypertension and diabetic nephropathy with $125 \mathrm{mg}$ palosuran twice daily for 13.5 days. There were no significant changes in renal function parameters such as GFR, renal blood flow, and filtration fraction. However, within the 13.5 days of treatment, the 24 -h urinary albumin excretion rate was significantly decreased by approximately $24 \%$ in comparison to baseline. Although the relationship between the 24-h urinary albumin excretion rate and the effect on renal function has not been completely elucidated, it is accepted as a clinical marker of cardiorenal disease (de Zeeuw, 2004; Lane, 2004; Brantsma et al., 2006). Therefore, the authors of the study concluded that palosuran may improve the current treatment of diabetic nephropathy (Sidharta et al., 2006). However, there are several concerns with the study, including the very low number of patients treated $(n=19)$, and the lack of a suitable control group that was not treated. In addition, for ethical reasons, the patients enrolled in the trial did not discontinue the use of medications such as angiotensinconverting enzyme inhibitors and angiotensin receptor blockers which are known to reduce macroalbuminuria. Therefore, the considerable reduction in urinary albumin secretion cannot be attributed to palosuran alone, as possible drug-drug interactions could rather be the cause. Interestingly, 7 months before Sidharta et al. (2006) published their paper, Actelion Pharmaceuticals, the manufacturer of palosuran, declared that efficacy data from three individual proof-of-concept studies did not support a full-fledged clinical trial of on the indication of diabetic nephropathy (Desai et al., 2008).

Nevertheless, Sidharta et al. (2009) later published a second paper on palosuran's effect on patients with type 2 diabetes. Although the authors had previously concluded that more patients and different dosing regimens should be used in future studies, they used approximately the same number of patients $(n=20)$ and the same dosing regimen ( $125 \mathrm{mg}$ twice daily). To evaluate $\beta$-cell function, a hyperglycemic glucose clamp was applied (DeFronzo et al., 1979; Elahi, 1996) and the second-phase insulin response was chosen as the primary efficacy end-point. Palosuran did not affect the second-phase insulin response, nor did it affect the first-phase response. No effects on the glucose infusion rate were observed during the treatment. $\beta$-Cell secretory capacity was also assessed with a meal tolerance test and was found to be unchanged with palosuran. They also investigated insulin sensitivity without finding differences between palosuran and vehicle-treated groups. They concluded that palosuran did not have an influence on insulin secretion, insulin sensitivity or glucose levels in patients with type 2 diabetes treated with palosuran (Sidharta et al., 2009).
It could be hypothesized that the exposure to palosuran was too low to invoke an effect, yet it was enough to alter urinary albumin secretion in their previous study.

This can be explained, not only by the concomitant medication used by patients in their first study, but also by palosuran's important ability to bind albumin. In fact, palosuran has recently been identified as a somatostatin receptor antagonist (Malagon et al., 2008) which is known to lower both glucose and albuminuria levels in diabetic models (Segev et al., 2004; Strowski et al., 2006). Therefore, the palosuran concentration may indeed have been too low to inhibit the UII system. The regimen of $125 \mathrm{mg}$ of palosuran twice daily used by Sidharta et al. (2006) results in a peak plasma concentration $\left(C_{\max } \leq 260 \mathrm{nM}\right)$ that is $\geq 10$-fold lower than the UT affinity of palosuran determined by Behm et al. (2008). In fact, it is an underestimation as it assumes that palosuran concentrations stay constant and that there are no native ligands (i.e., hUII, URP) to compete for UT occupancy. With these factors considered, the Schild analysis suggests that significant UT antagonism would only be observed at $\approx 200 \mu \mathrm{M}$ palosuran, a concentration clearly never attained with a 125-mg dosing regimen (Behm et al., 2008). In addition to the in vivo palosuran studies, the in vitro studies also seem to have been under-treated. As mentioned previously, both studies by Clozel (Clozel et al., 2004, 2006) administered approximately half the amount of palosuran necessary for efficacy. The observation of beneficial effects in the rat under these circumstances suggests a lack of UT affinity and an "off-target" effect of palosuran (Behm et al., 2008). In fact, the initial study defining palosuran affinity and selectivity by Clozel et al. (2004), as they have not specified, may or may not have randomized their tissue samples. Randomization is imperative in minimizing "reactivity bias" producing apparent, yet erroneous, results.

Therefore, caution must be used when interpreting data generated with the use of palosuran as it is not an optimal pharmacological tool. It interacts poorly with "non-human" UT receptors and losses affinity in intact cell and tissue-based assays. In addition, several actions of palosuran cannot be replicated using the alternative antagonist SB-710411 (Albertin et al., 2006; Spinazzi et al., 2006). However, results obtained with more reliable UT receptor antagonists, such as urantide and SB-611812, have demonstrated positive health effects that should be explored further. Although a clinical equivalent is no yet ready for commercial use, further research should be conducted on the matter as it has promise.

\section{PIPERAZINO-ISOINDOLINONE BASED ANTAGONIST}

Most recently, Johnson and Johnson discovered a non-peptide UII antagonist based on the piperazino-isoindolinone scaffold. The structure $7 \mathrm{a}$ exhibits single-digit nanomolar potencies in the rat FLIPR assay $\left(\mathrm{IC}_{50}=1.0 \mathrm{nM}\right)$ and in the hUT binding assay $\left(K_{\mathrm{i}}=4.0 \mathrm{nM}\right)$. It also exhibits potent antagonism in the human calcium flux assay $\left(\mathrm{IC}_{50}=8.0 \mathrm{nM}\right)$. 7a Blocks the effects of UII with $74 \%$ inhibition at $100 \mathrm{nM}$ in the in vitro rat aortic ring assay. In vivo, in a rat ear-flush model, it reverses the increased ear pinna temperature induced by UII at $10 \mathrm{mg} / \mathrm{kg}$. The $7 \mathrm{a}$ compound binds strongly and specifically to the human UII receptor, but its oral bioavailability could be improved upon (Lawson et al., 2009). Nevertheless, this new compound presents interesting research opportunity for treatment. 


\section{CONCLUSION}

Although only some 12 years have passed since UII receptor has been identified, the UII system has been shown as a major contributor to cardiovascular diseases, metabolic syndrome, and renal diseases. It seems that all three disease states are inter-related through several mechanisms and share a catalyst in the poor lifestyle choices of many in the Western world. Inhibition of the UII

\section{REFERENCES}

Albertin, G., Casale, V., Ziolkowska, A., Spinazzi, R., Malendowicz, L. K., Rossi, G. P., and Nussdorfer, G. G. (2006). Urotensin-II and UIIreceptor expression and function in the rat adrenal cortex. Int. J. Mol. Med. 17, 1111-1115.

Ames, R. S., Sarau, H. M., Chambers, J. K., Willette, R. N., Aiyar, N. V., Romanic, A. M., Louden, C. S., Foley, J. J., Sauermelch, C. F., Coatney, R. W., Ao, Z., Disa, J., and Holmes, S. D., Stadel, J. M., Martin, J. D., Liu, W. S., Glover, G. I., Wilson, S., McNulty, D. E., Ellis, C. E., Elshourbagy, N. A., Shabon, U., Trill, J. J., Hay, D. W., Ohlstein, E. H., Bergsma, D. J., and Douglas, S. A. (1999). Human urotensin-II is a potent vasoconstrictor and agonist for the orphan receptor GPR14. Nature 401, 282-286.

Ashton, N. (2006). Renal and vascular actions of urotensin II. Kidney Int. 70, 624-629.

Balat, O., Aksoy, F., Kutlar, I., Ugur, M., Iyikosker, H., Balat, A., and Anarat, R. (2005). Increased plasma levels of urotensin-II in preeclampsiaeclampsia: a new mediator in pathogenesis? Eur. J. Obstet. Gynecol. Reprod. Biol. 120, 33-38.

Behm, D. J., Herold, C. L., Ohlstein, E. H., Knight, S. D., Dhanak, D., and Douglas, S. A. (2002). Pharmacological characterization of SB-710411(Cpa-c[D-Cys-Pal-DTrp-Lys-Val-Cys]-Cpa-amide), a novel peptidic urotensin-II receptor antagonist. Br. J. Pharmacol. 137, 449-458.

Behm, D. J., McAtee, J. J., Dodson, J. W., Neeb, M. J., Fries, H. E., Evans, C. A., Hernandez, R. R., Hoffman, K. D., Harrison, S. M., Lai, J. M., Wu, C., Aiyar, N. V., Ohlstein, E. H., and Douglas, S. A. (2008). Palosuran inhibits binding to primate UT receptors in cell membranes but demonstrates differential activity in intact cells and vascular tissues. Br. J. Pharmacol. 155, 374-386.

Bergman, R. N., and Ader, M. (2000). Free fatty acids and pathogenesis of type 2 diabetes mellitus. Trends Endocrinol. Metab. 11, 351-356.

Bohm, F., and Pernow, J. (2002). Urotensin II evokes potent vasoconstriction in humans 25-27.

Bottrill, F. E., Douglas, S. A., Hiley, C. R., and White, R. (2000). Human urotensin-II is an endotheliumdependent vasodilator in rat small arteries. Br. J. Pharmacol. 130, 1865-1870.

Bousette, N., D’Orleans-Juste, P., Kiss, R. S., You, Z., Genest, J., Al-Ramli, W., Qureshi, S. T., Gramolini, A., Behm, D., Ohlstein, E. H., Harrison, S. M., Douglas, S. A., and Giaid, A. (2009). Urotensin II receptor knockout mice on an ApoE knockout background fed a high-fat diet exhibit an enhanced hyperlipidemic and atherosclerotic phenotype. Circ. Res. 105, 686-695.

Bousette, N., Hu, F., Ohlstein, E. H., Dhanak, D., Douglas, S. A. and Giaid, A. (2006a). Urotensin-II blockade with SB-611812 attenuates cardiac dysfunction in a rat model of coronary artery ligation. J. Mol. Cell. Cardiol. 41, 285-295.

Bousette, N., Pottinger, J., Ramli, W., Ohlstein, E. H., Dhanak, D., Douglas, S. A., and Giaid, A. (2006b). Urotensin-II receptor blockade with SB-611812 attenuates cardiac remodeling in experimental ischemic heart disease. Peptides 27, 2211-2214.

Bousette, N., Patel, L., Douglas, S. A., Ohlstein, E. H., and Giaid, A. (2004). Increased expression of urotensin II and its cognate receptor GPR14 in atherosclerotic lesions of the human aorta. Atherosclerosis 176, 117-123.

Brantsma, A. H., Baker, S. J., de Zeeuw, D., de Jong, P. E., and Gansevoort, R. T. (2006). Urinary albumin excretion as a predictor of the development of hypertension in the general population. J. Am. Soc. Nephrol. 17, 331-335.

Camarda, V., Rizzi, A., Calò, G., Gendron, G., Perron, S. I., Kostenis, E., Zamboni, P., Mascoli, F., and Regoli, D. (2002). Effects of human urotensin II in isolated vessels of various species; comparison with other vasoactive agents. Naunyn Schmiedebergs Arch. Pharmacol. 365 141-149.

Camarda, V., Song, W., Marzola, E., Spagnol, M., Guerrini, R., Salvadori, in vivo. Br. J. Pharmacol. 135

system has been studied with UT receptor antagonists with positive results on health in experimental animals, although a potent and safe antagonist that can be used in human is yet to be found.

\section{ACKNOWLEDGMENTS}

Dr. Adel Giaid is supported by the Canadian Institute for Health Research and the Heart and Stroke Foundation of Quebec.

S., Regoli, D., Thompson, J. P., Rowbotham, D. J., Behm, D. J., Douglas, S. A., Calo', G., and Lambert, D. G. (2004). Urantide mimics urotensin-II induced calcium release in cells expressing recombinant UT receptors. Eur. J. Pharmacol. 498, 83-86.

Cheung, B. M. Y., Leung, R., Man, Y. B. and Wong, L. Y. (2004). Plasma concentration of urotensin II is raised in hypertension. J. Hypertens. 22, 1341-1344.

Clozel, M., Binkert, C., BirkerRobaczewska, M., Boukhadra, C., Ding, S.-S., Fischli, W., Hess, P., Mathys, B., Morrison, K. Müller, C., Müller, C., Nayler, O. Qiu, C., Rey, M., Scherz, M. W. Velker, J., Weller, T., Xi, J. F., and Ziltener, P. (2004). Pharmacology of the urotensin-II receptor antagonist palosuran (ACT058362; 1-[2-(-benzyl-4-hydroxypiperidin-1-yl)-ethyl]-3-(2-methylquinolin-4-yl)-urea sulphate salt): first demonstration of a pathophysiological role of the urotensin system. J. Pharmacol. Exp. Ther. 311 , 204-212.

Clozel, M., Hess, P., Qui, C., Ding, S. S. and Rey, M. (2006). The urotensinII receptor antagonist palosuran improves pancreatic and renal function in diabetic rats. J. Pharmacol. Exp. Ther. 316, 1115-1121.

Colton, J. M., Yano, K., Waugh, D. and Hazon, N. (1996). Distribution and molecular forms of urotensin II and its role in cardiovascular regulation in vertebrates. J. Exp. Zool. 275 , 226-238.

Dai, H. Y., Kang, W. Q., Wang, X. Yu, X. J., Li, Z. H., Tang, M. X., Xu, D. L., Li, C. W., Zhang, Y., and Ge, Z. M. (2007). The involvement of transforming growth factor-betal secretion in urotensin II-induced collagen synthesis in neonatal cardiac fibroblasts. Regul. Pept. 140, 88-93.

de Zeeuw, D. (2004). Should albuminuria be a therapeutic target in patients with hypertension and diabetes? Am. J. Hypertens. 17, 11S-15S.

DeFronzo, R. A., Tobin, J. D., and Andres, R. (1979). Glucose clamp technique: a method for quantifying insulin secretion and resistance. Am. J. Physiol. 237, E214-E223.
Desai, N., Sajjad, J., and Frishman, W. H. (2008). Urotensin II: a new pharmacologic target in the treatment of cardiovascular disease. Cardiol. Rev. 16, 142-153.

Disa, J., Floyd, L. E., Edwards, R. M., Douglas, S. A., and Aiyar, N. V. (2005). Identification and characterization of binding sites for human urotensin-II in Sprague-Dawley rat renal medulla using quantitative receptor autoradiography. Peptides 27, 1532-1537.

Djordjevic, T., BelAiba, R. S., Bonello, S., Pfeilschifter, J., Hess, J., and Görlach, A. (2005). Human urotensin II is a novel activator of NADPH oxidase in human pulmonary artery smooth muscle cells. Arterioscler. Thromb. Vasc. Biol. 25, 519-525.

Douglas, S. A. (2003). Human urotensin-II as a novel cardiovascular target: "heart" of the matter or simply a fishy "tail"? Curr. Opin. Pharmacol. 3, 159-167.

Douglas, S. A., Sulpizio, A. C., Piercy, V., Sarau, H. M., Ames, R. S., Aiyar, N. V., Ohlstein, E. H., and Willette, R. N. (2000). Differential vasoconstrictor activity of human urotensin-II in vascular tissue isolated from the rat, mouse, dog, pig, marmoset and cynomolgus monkey. Br. J. Pharmacol. 131, 1262-1274.

Douglas, S. A., Dhanak, D., and Johns, D. G. (2004a). From "gills to pills": urotensin-II as a regulator of mammalian cardiorenal function. Trends Pharmacol. Sci. 25, 76-85

Douglas, S. A., Naselsky, D., Ao, Z., Disa, J., Herold, C. L., Lynch, F., and Aiyar, N. V. (2004b). Identification and pharmacological characterization of native, functional human urotensinII receptors in rhabdomyosarcoma cell lines. Br. J. Pharmacol. 142, 921-932.

Douglas, S. A., and Ohlstein, E. H. (2000). Human urotensin-II, the most potent mammalian vasoconstrictor identified to date, as a therapeutic target for the management of cardiovascular disease. Trends Cardiovasc. Med. 131, 1262-1274.

Douglas, S. A., Tayara, L., Ohlstein, E. H., Halawa, N., and Giaid, A (2002). Congestive heart failure and expression of myocardial urotensin II. Lancet 359, 1990-1997. 
Elahi, D. (1996). In praise of the hyperglycaemic clamp. A method for assessment of beta-cell sensitivity and insulin resistance. Diabetes Care 19, 278-286.

El-Atat, F. A., Stas, S. N., McFarlane, S. I., and Sowers, J. R. (2004). The relationship between hyperinsulinemia, hypertension and progressive renal disease. J. Am. Soc. Nephrol. 15, 2816-2827.

Elshourbagy, N. A., Douglas, S. A., Shabon, U., Harrison, S., Duddy, G., Sechler, J. L., Ao, Z., Maleeff, B. E., Naselsky, D., Disa, J., and Aiyar, N. V. (2002). Molecular and pharmacological characterization of genes encoding urotensin-II peptides and their cognate G-proteincoupled receptors from the mouse and monkey. Br. J. Pharmacol. 136, 9-22.

Fernandez-Real, J. M., and Ricart, W. (2003). Insulin resistance and chronic cardiovascular inflammatory syndrome. Endocr. Rev. 24, 278-301.

Gardiner, S. M., March, J. E., Kemp, P. A., Maguire, J. J., Kuc, R. E., Davenport, A. P., and Bennett, T. (2006). Regional heterogeneity in the haemodynamic responses to urotensin II infusion in relation to UT receptor localisation. Br. J. Pharmacol. 147, 612-621.

Gibson, A. (1987). Complex effects of Gillichthys urotensin II on rat aortic strips. Br. J. Pharmacol. 91, 205-212.

Gray, G. A., Jones, M. R., and Sharif, I. (2001). Human urotensin II increases coronary perfusion pressure in the isolated rat heart. Potentiation by nitric oxide synthase and cyclooxygenase inhibition. Life Sci. 69, 175-180.

Grundy, S. M., Cleeman, J. I., and Daniels, S. R. (2005). Diagnosis and management of the metabolic syndrome: an American Heart Association/National Heart, Lung, and Blood Institute scientific statement. Circulation 112, 2735-2752.

Gruson, D., Rousseau, M. F., Ahn, S. A., van Linden, F., and Ketelslegers, J. M. (2006). Circulating urotensin II levels in moderate to severe congestive heart failure: its relations with myocardial function and well established neurohormonal markers. Peptides 27, 1527-1531.

Hassan, G. S., Chouiali, F., Saito, T., Hu, F., Douglas, S. A., Ao, Z., Willette, R. N., Ohlstein, E. H., and Giaid, A. (2003). Effect of human urotensin-II infusion on hemodynamics and cardiac function. Can. J. Physiol. Pharmacol. 81, 125-128.
Hassan, G. S., Douglas, S. A., Ohlstein, E. H, and Giaid, A. (2005). Expression of urotensin-II in human coronary atherosclerosis. Peptides 26, 2462-2472.

Heller, J., Schepke, M., Neef, M., Woitas, R., Rabe, C., and Sauerbruch, T. (2002). Increased urotensin II plasma levels in patients with cirrhosis and portal hypertension. J. Hepatol. 37, 767-772.

Herold, C. L., Behm, D. J., Buckley, P. T., Foley, J. J., Wixted, W. E., Sarau, H. M., and Douglas, S. A. (2003). The neuromedin B receptor antagonist, BIM-23127, is a potent antagonist at human and rat urotensinII receptors. Br. J. Pharmacol. 139, 203-207.

Hunt, S. A., Baker, D. W., Chin, M. H., Cinquegrani, M. P., Feldman, A. M. Francis, G. S., Ganiats, T. G., Goldstein, S., Gregoratos, G., Jessup, M. L., Noble, R. J., Packer, M., Silver, M. A., Stevenson, L. W., Gibbons, R. J., Antman, E. M., Alpert, J. S., Faxon, D. P., Fuster, V., Gregoratos, G., Jacobs, A. K., Hiratzka, L. F., Russell, R. O., Smith, S. C. Jr., and American College of Cardiology/American Heart Association Task Force on Practice Guidelines (Committee to Revise the 1995 Guidelines for the Evaluation and Management of Heart Failure), International Society for Heart and Lung Transplantation, Heart Failure Society of America. (2001). ACC/AHA Guidelines for the evaluation and management of chronic heart failure in the adult: executive summary. Circulation 104, 2996-3007.

IDF Epidemiology Task Force Consensus Group. (2005). The metabolic syndrome - a new worldwide definition. Lancet 366, 1059-1062

Ishihata, A., Ogaki, T., Aita, T., and Katano, Y. (2005). Role of prostaglandins in urotensin IIinduced vasodilation in the coronary arteries of aged rats. Eur. J. Pharmacol. 523, 119-126.

Ishihata, A., Sakai, M., and Katano, Y. (2006). Vascular contractile effect of urotensin II in young and aged rats: influence of aging and contribution of endothelial nitric oxide. Peptides 27, 80-86.

Johns, D. G., Ao, Z., Naselsky, D., Herold, C. L., Maniscalco, K., Sarov-Blat, L., Steplewski, K., Aiyar, N., and Douglas, S. A. (2004). UrotensinII-mediated cardiomyocyte hypertrophy: effect of receptor antagonism and role of inflammatory mediators. Arch. Pharmacol. 370, 238-250.
Katano, Y., Ishihata, A., Aita, T., Ogaki, T., and Horie, T. (2000). Vasodilator effect of urotensin II, one of the most potent vasoconstricting factors, on rat coronary arteries. Eur. J. Pharmacol. 402, 209-211.

Khan, S. Q., Bhandari, S. S., Quinn, P., Davies, J. E., and Ng, L. L. (2007). Urotensin II is raised in acute myocardial infarction and low levels predict risk of adverse clinical outcome in humans. Int. J. Cardiol. 117 323-327.

Lach, E. B., Broad, S., and Rozengurt, E. (1995). Mitogenic signalling by transfected neuromedin B receptors in Rat-1 cells. Cell Growth Differ. 6 , 1427-1435.

Lacza, Z., and Busija, D. W. (2006). Urotensin-II is a nitric oxidedependent vasodilator in the pial arteries of the newborn pig. Life Sci. 78, 2763-2766.

Lane, J. T. (2004). Microalbuminuria as a marker of cardiovascular and renal risk in type 2 diabetes mellitus: a temporal perspective. Am. J. Physiol. Renal Physiol. 286, F442-F450.

Langham, R. G., Kelly, D. J., Gow, R. M., Zhang, Y., Dowling, J. K., Thomson, N. M., and Gilbert, R. E. (2004). Increased expression of urotensin II and urotensin II receptor in human diabetic nephropathy. Am. J. Kidney Dis. 44, 826-831.

Lapp, H., Boerrigter, G., CostelloBoerrigter, L. C., Jaekel, K., Scheffold, T., Krakau, I., Schramm, M. Guelker, H., and Stasch, J. P. (2004). Elevated plasma human urotensinII-like immunoreactivity in ischemic cardiomyopathy. Int. J. Cardiol. 94 93-97.

Lawson, E. D., Luci, D. K., Ghosh, S. Kinney, W. A., Reynolds, C. H., Qi, J., Smith, C. E., Wang, Y., Minor, L. K. Haertlein, B. J., Parry, T. J., Damiano, B. P., and Maryanoff, B. E. (2009). Nonpeptide urotensin-II receptor antagonists: a new ligand class based on piperazino-phthalimide and piperazino-isoindolinone subunits. J. Med. Chem. 52, 7432-7445.

Li, L., Yuan, W. J., and Su, D. F. (2004). Effects of rat urotensin II on coronary flow and myocardial eNOS protein expression in isolated rat heart. Acta Pharmacol. Sin. 25, 1444-1449.

Lim, M., Honisett, S., Sparkes, C. D. Komesaroff, P., Kompa, A., and Krum, H. (2004). Differential effect of urotensin II on vascular tone in normal subjects and patients with chronic heart failure. Circulation 109, 1212-1214.

Liu, Q., Pong, S. S., Zeng, Z., Zhang, Q., Howard, A. D., Williams, D. L. Jr.
Davidoff, M., Wang, R., Austin, C. P., McDonald, T. P., Bai, C., George, S. R., Evans, J. F., and Caskey, C. T. (1999). Identification of urotensin II as the endogenous ligand for the orphan G-protein-coupled receptor GPR14. Biochem. Biophys. Res. Commun. 266, 174-178.

MacLean, M. R., Alexander, D., Stirrat, A., Gallagher, M., Douglas, S. A., Ohlstein, E. H., Morecroft, I. and Polland, K. (2000). Contractile responses to human urotensin-II in rat and human pulmonary arteries: effect of endothelial factors and chronic hypoxia in the rat. Br. J. Pharmacol. 130, 201-204.

Maguire, J. J., Kuc, R. E., and Davenport, A. P. (2000). Orphan-receptor ligand human urotensin II: receptor localization in human tissues and comparison of vasoconstrictor responses with endothelin-1. Br. J. Pharmacol. 131, 441-446.

Maguire, J. J., Kuc, R. E., Wiley, K. E., Kleinz, M. J., and Davenport, A. P. (2004). Cellular distribution of immunoreactive urotensinII in human tissues with evidence of increased expression in atherosclerosis and a greater constrictor response of small compared to large coronary arteries. Peptides 25, 1767-1774.

Malagon, M. M., Molina, M., Gahete, M. D., Duran-Prado, M., MartinezFuentes, A. J., Alcain, F. J., Tonon, M. C., Leprince, J., Vaudry, H., Castaño, J. P., and Vazquez-Martinez, R. (2008). Urotensin II and urotensin II-related peptide activate somatostatin receptor subtypes 2 and 5 . Peptides 29, 711-720.

Mallamaci, F., Cutrupi, S., Pizzini, P., Tripepi, G., and Zoccali, C. (2005). Urotensin II in end-stage renal disease: an inverse correlate of sympathetic function and cardiac natriuretic peptides. J. Nephrol. 18, 727-732.

Matsushita, M., Shichiri, M., Imai, T., Iwashina, M., Tanaka, H., Takasu, N., and Hirata, Y. (2001). Co-expression of urotensin II and its receptor (GPR14) in human cardiovascular and renal tissues. J. Hypertens. 19, 2185-2190.

Ng, L. L., Loke, I., O’Brien, R. J., Squire I. B., and Davies, J. E. (2002). Plasma urotensin in human systolic heart failure. Circulation 106, 2877-2880.

Onan, D., Pipolo, L., Yang, E., Hannan, R. D., and Thomas, W G. (2004). Urotensin II promotes hypertrophy of cardiac myocytes via mitogen-activated protein kinases. Mol. Endocrinol. 18, 2344-2354. 
Ovcharenko, E., Abassi, Z., Rubinstein, I., Kaballa, A., Hoffman, A., and Winaver, J. (2006). Renal effects of human urotensin-II in rats with experimental congestive heart failure. Nephrol. Dial. Transplant. 21, 1205-1211.

Pakala, R. (2007). Role of urotensin II in atherosclerotic cardiovascular diseases. Cardiovasc. Revasc. Med. 9, 166-178.

Patacchini, R., Santicioli, P., Giuliani, S., Grieco, P., Novellino, E., Rovero, P., and Maggi, C. A. (2003). Urantide: an ultrapotent urotensin II antagonist peptide in rat aorta. $\mathrm{Br}$. J. Pharmacol. 140, 1155-1158.

Rajala, M. W., and Scherer, P. E. (2003). The adipocyte - at the crossroads of energy homeostasis, inflammation, and atherosclerosis. Endocrinology 144, 3765-3673.

Rakowski, E., Hassan, G. S., Dhanak, D., Ohlstein, E. H., Douglas, S. A., and Giaid, A. (2005). A role for urotensin II in restenosis following balloon angioplasty: use of a selective UT receptor blocker. J. Mol. Cell. Cardiol. 39, 785-791.

Richards, A. M., Nicholls, M. G., Lainchbury, J. G., Fisher, S., and Yandle, T. G. (2002). Plasma urotensin II in heart failure. Lancet 360, 545-546.

Russell, F. D. (2008). Urotensin II in cardiovascular regulation. Vasc. Health Manag. 4, 775-785.

Russell, F. D., Meyers, D., Galbraith, A. J., Bett, N., Toth, I., Kearns, P., and Molenaar, P. (2003). Elevated plasma levels of human urotensin-II immunoreactivity in congestive heart failure. Am. J. Physiol. Heart Circ. Physiol. 285, H1576-H1581.

Russell, F. D., and Molenaar, P. (2004). Investigation of signalling pathways that mediate the inotropic effect of urotensin-II in human heart. Cardiovasc. Res. 63, 673-681.

Saltiel, A. R., and Kahn, C. R. (2001). Insulin signalling and the regulation of glucose and lipid metabolism. Nature 414, 799-807.

Sano, M., Fukuda, K., Kodama, H., Pan, J., Saito, M., Matsuzaki, J., Takahashi, T., Makino, S., Kato, T., and Ogawa, S. (2000). Interleukin-6 family of cytokines mediate angiotensin II-induced cardiac hypertrophy in rodent cardiomyocytes. J. Biol. Chem. 275, 29717-22923.

Sauzeau, V., Le Mellionnec, E., Bertoglio, J., Scalbert, E., Pacaud, P., and Loirand, G. (2001). Human urotensin II-induced contraction and arterial smooth muscle cell proliferation are mediated by RhoA and Rho-kinase. Circ. Res. 88, 1102-1104.

Segev, Y., Eshet, R., Rivkis, I., Hayat, C. Kachko, L., Phillip, M., and Landau, D. (2004). Comparison between somatostatin analogues and ACE inhibitor in the NOD mouse model of diabetic kidney disease. Nephrol. Dial. Transplant. 19, 3021-3028.

Shenouda, A., Douglas, S. A., Ohlstein, E. H., and Giaid, A. (2002). Localization of urotensin-II immunoreactivity in normal human kidneys and renal carcinoma. J. Histochem. Cytochem. 50, 885-889.

Sidharta, P. N., Rave, K., Heinemann, L., Chiossi, E., Krähenbühl, S., and Dingemanse, J. (2009). Effect of the urotensin-II receptor antagonist palosuran on secretion of and sensitivity to insulin in patients with type 2 diabetes mellitus. $\mathrm{Br}$. J. Clin. Pharmacol. 68, 502-510.

Sidharta, P. N., Wagner, F. D., Bohnemeier, H., Jungnik, A., Halabi, A., Krähenbühl, S., Chadha-Boreham, H., and Dingemanse, J. (2006). Pharmacodynamics and pharmacokinetics of the urotensin II receptor antagonist palosuran in macroalbuminuric, diabetic patients. Clin. Pharmacol. Ther. 80, 246-256.

Silvestre, R. A., Edigo, E. M., Hernández, R., Leprince, J., Chatenet, D., Tollemer, H., Chartrel, N., Vaudry, H., and Marco, J. (2004). Urotensin-II is present in pancreatic extracts and inhibits insulin release in the perfused rat pancreas. Eur. J. Endocrinol. 151, 803-809.

Silvestre, R. A., Rodriguez-Gallardo, J., Egido, E. M., and Marco, J. (2001). Inhibition of insulin release by urotensin II-a study on the perfused rat pancreas. Horm. Metab. Res. 33, 379-381.

Simpson, C. M., Penny, D. J., Stocker, C. F., and Shekerdemian, L. S. (2006). Urotensin II is raised in children with congenital heart disease. Heart 92, 983-984.

Sondermeijer, B., Komp, A., Komesaroff, P., and Krum, H. (2005). Effects of exogenous urotensin-II on vascular tone in skin microcirculation of patients with essential hypertension. Am. J. Hypertens. 22, 1341-1344.

Song, W., Abdel-Razik, A. E., Lu, W., Ao, Z., Johns, D. G., Douglas, S. A., Balment, R. J., and Ashton, N. (2006). Urotensin II and renal function in the rat. Kidney Int. 69, 1360-1368.

Sowers, J. R. (2004). Insulin resistance and hypertension. Am. J. Physiol. Heart Circ. Physiol. 286, H1597-H1602.
Spinazzi, R., Albertin, G., Nico, B. Guidolin, D., Di Liddo, R., Rossi, G. P., Ribatti, D., and Nussdorfer, G. G. (2006). Urotensin-II and its receptor (UT-R) are expressed in rat brain endothelial cells, and urotensin-II via UT-R stimulates angiogenesis in vivo and in vitro. Int. J. Mol. Med. 18, 1107-1112.

Strowski, M. Z., Cashen, D. E., Birzin E. T., Yang, L., Singh, V., Jacks, T. M., Nowak, K. W., Rohrer, S. P. Patchett, A. A., Smith, R. G., and Schaeffer, J. M. (2006). Antidiabetic activity of a highly potent and selective nonpeptide somatostatin receptor subtype-2 agonist. Endocrinology 147, 4664-4673.

Suguro, T., Watanabe, T., Ban, Y., Kodate, S., Misaki, A., Hirano, T., Miyazaki, A., and Adachi, M. (2007). Increased human urotensin II levels are correlated with carotid atherosclerosis in essential hypertension. Am. J. Hypertens. 20, 211-217.

Suzuki, S., Wenyi, Z., Hirai, M., Hinokio Y., Suzuki, C., Yamada, T., Yoshizumi, S., Suzuki, M., Tanizawa, Y., Matsutani, A., and Oka, Y. (2004). Genetic variations at urotensin II and urotensin II receptor genes and risk of type 2 diabetes mellitus in Japanese. Peptides 25, 1803-1808.

Tamura, K., Okazaki, M., Tamura M., Isozumi, K., Tasaki, H., and Nakashima, Y. (2003). Urotensin II-induced activation of extracellular signal-regulated kinase in cultured vascular smooth muscle cells: involvement of cell adhesionmediated integrin signalling. Life Sci. 72, 1049-1060.

Totsune, K., Takahashi, K., Arihara, Z. Sone, M., Ito, S., and Murakami, O. (2003). Increased plasma urotensin II levels in patients with diabetes mellitus. Clin. Sci. 104, 1-5.

Totsune, K., Takahashi, K., Arihara, Z. Sone, M., Murakami, O., Ito, S. Kikuya, M., Ohkubo, T., Hashimoto, J., and Imai, Y. (2004). Elevated plasma levels of immunoreactive urotensin II and its increased urinary excretion in patients with type 2 diabetes mellitus: association with progress of diabetic nephropathy. Peptides 25, 1809-1814.

Tölle, M., and van der Giet, M (2008). Cardiorenovascular effects of urotensin II and relevance of the UT receptor. Peptides 29, 743-763.

Totsune, K., Takahashi, K., Arihara, Z. Sone, M., Satoh, F., Ito, S., Kimura Y., Sasano, H., and Murakami, O. (2001). Role of urotensin II in patients with on dialysis. Lancet 358 , 810-811.

Tzanidis, A., Hannan, R., Thomas, W., Onan, W., Autelitano, D., See, F., and Krum, H. (2001). Increased expression of urotensin II and its receptor in an experimental model of left ventricular myocardial infarction in the rat: implications for cardiac remodeling. Eur. Heart J. 22, 141.

Tzanidis, A., Hannan, R. D., and Thomas, W. G. (2003). Direct actions of urotensin II on the heart implications for cardiac fibrosis and hypertrophy. Circ. Res. 93, 246-253.

Wang, D., Iversen, J., Wilcox, C. S., and Strandgaard, S. (2003). Endothelial dysfunction and reduced nitric oxide in resistance arteries in autosomaldominant polycystic kidney disease. Kidney Int. 64, 1381-1388.

Watanabe, T., Pakala, R., and Katagiri, T. (2001a). Synergistic effect of urotensin II with mildly oxidized LDL on DNA synthesis in vascular smooth muscle cells. Circulation 104, 16-18.

Watanabe, T., Pakala, R., and Katagiri, T. (2001b). Synergistic effect of urotensin II with serotonin on vascular smooth muscle cell proliferation. J. Hypertens. 19, 2191-2196.

Watanabe, T., Koba, S., Katagiri, T., Pakala, R., and Benedict, C. R. (2002). Lysophosphatidylcholine potentiates the mitogenic effect of various vasoactive compounds on rabbit aortic smooth muscle cells. Jpn. Heart J. 43, 409-416.

Watanabe, T., Suguro, T., Kanome, T., Sakamoto, Y., Kodate, S., Hagiwara, T., Hongo, S., Hirano, T., Adachi, M., and Miyazaki, A. (2005). Human urotensin II accelerates foam cell formation in human monocytederived macrophage. Hypertension 46, 738-744.

Wellen, K. E., and Hotamisligil, G. S. (2003). Obesity-induced inflammatory changes in adipose tissue. $J$. Clin. Invest. 112, 1785-1788.

Zhang, A. Y., Chen, Y. -F., Zhang, D. X., Yi, F. X., Qi, J., Andrade-Gordon, P., de Garavilla, L., Li, P. L., and Zou, A. P. (2003). Urotensin II is a nitric oxide-dependent vasodilator and natriuretic peptide in the rat kidney. Am. J. Physiol. Renal Physiol. 385, F792-F798.

Zhang, Y., Li, J., Cao, J., Chen, J., Yan, J., Zhang, Z., Du, J., and Tang, C. (2002). Effect of chronic hypoxia on contents of urotensin II and its functional receptors in rat myocardium. Heart Vessels 16, 64-68.

Zhou, P., Wu, S. Y., Yu, C. F., Wang, H., Tang, C. S., Lin, L., and Yuan, 
W. J. (2003). Effects of urotensin II on isolated rat hearts under normal perfusion and ischemia reperfusion. Sheng $L i$ Xue Bao 55, 442-448.

Zhu, Y.-C., Zhu, Y.-Z., and Moore, P. K. (2006). The role of urotensin II in cardiovascular and renal physiology and diseases. Br. J. Pharmacol. 148, 884-901.

Zoccali, C., Mallamaci, F., Tripepi, G., Cutrupi, S., Pizzini, P., and Malatino,
L. (2006). Urotensin II is an inverse predictor of incident cardiovascular events in end-stage renal disease. Kidney Int. 69, 1253-1258.

Zou, Y., Nagai, R., and Yamazaki, T. (2001). Urotensin II induces hypertrophic responses in cultured cardiomyocytes from neonatal rats. FEBS Lett. 508, 57-60.

Conflict of Interest Statement: The authors declare that the research was conducted in the absence of any commercial or financial relationships that could be construed as a potential conflict of interest.

Received: 28 June 2010; accepted: 05 July 2011; published online: 22 July 2011.

Citation: Tsoukas P, Kane É and Giaid A (2011) Potential clinical implications of the urotensin II receptor antagonists. Front. Pharmacol. 2:38. doi: 10.3389/fphar.2011.00038
This article was submitted to Frontiers in Cardiovascular and Smooth Muscle Pharmacology, a specialty of Frontiers in Pharmacology.

Copyright (c) 2011 Tsoukas, Kane and Giaid. This is an open-access article subject to a non-exclusive license between the authors and Frontiers Media SA, which permits use, distribution and reproduction in other forums, provided the original authors and source are credited and other Frontiers conditions are complied with. 